CHANGING INEQUALITY IN MARKETS FOR WORKPLACE AMENITIES

Daniel S. Hamermesh

Working Paper 6515 


\section{CHANGING INEQUALITY IN MARKETS FOR WORKPLACE AMENITIES}

Daniel S. Hamermesh

Working Paper 6515

http://www.nber.org/papers/w6515

\section{NATIONAL BUREAU OF ECONOMIC RESEARCH 1050 Massachusetts Avenue \\ Cambridge, MA 02138 \\ April 1998}

I thank Stephen Bronars, Caroline Hoxby, Steven Raphael, Takashi Yamashita and participants in seminars at several universities for useful comments; John Ruser for help with understanding the American injury data, Jan van Ours for providing me the unpublished Dutch data, David Trybula for extremely careful and energetic research assistance, the Russell Sage Foundation for support under grant 85-97-03 and the National Science Foundation for support under grant SBR-9422429. Any opinions expressed are those of the author and not those of the National Bureau of Economic Research.

(C) 1998 by Daniel S. Hamermesh. All rights reserved. Short sections of text, not to exceed two paragraphs, may be quoted without explicit permission provided that full credit, including $\bigcirc$ notice, is given to the source. 
Changing Inequality in Markets

for Workplace Amenities

Daniel S. Hamermesh

NBER Working Paper No. 6515

April 1998

JEL Nos. J31, J28

ABSTRACT

We know that earnings inequality has increased sharply in the United States since the late 1970s, but there has been no evidence on the changing inequality of nonmonetary aspects of work nor on how any such changes are related to changes in earnings. I begin by studying patterns of interindustry differences in occupational injuries during 1979-95, breaking the total burden of injuries into its components, risk of injury and injury duration. In those industries where earnings rose relatively, we observed a relative drop in injury rates and in the total burden of injuries. Obversely, during the 1960 s interindustry wage differentials narrowed, a decline that was associated with an increase in the relative risk of injury in high-wage industries. Evidence for large sectors of Dutch industry from 1974-92 suggests that injury rates there fell most in sectors where wages grew most rapidly. Examination of another workplace disamenity, working evenings or nights, shows analogous results for the period 1973-91: This disamenity was increasingly borne by low-wage male workers. Changes in earnings inequality thus have understated absolute changes in inequality in the returns to work. All the outcomes are readily explicable as income effects of exogenous shocks to the distribution of full earnings in the presence of skill-neutral changes in the cost of reducing workplace disamenities. Under reasonable assumptions we can infer from the estimates that the demand for the amenities, workplace safety and desirable work times, is highly income-elastic.

Daniel S. Hamermesh

Department of Economics

University of Texas

Austin, TX 78712-1173

and NBER

hamermesh@eco.utexas.edu 
I have long had relatively little faith in judging statistical results by formal tests of statistical significance. I believe that it is much more important to base conclusions on a wide range of evidence coming from different sources over a long period of time. [Milton Friedman, 1987, quoted in Hammond (1996, p. 202)]

\section{The General Problem}

Rising inequality of earnings has been the most striking development in the American labor market during the 1980s and 1990s (e.g., Bound and Johnson, 1992, and Juhn et al, 1993). While the United States is not unique in this phenomenon, inequality in the returns to labor-market activities has increased faster than in any of the other fifteen developed economies for which data are available (OECD, 1996). The accumulating and by-now immense attention to this phenomenon has been exclusively to changes in inequality in the monetary returns to work. We do not know whether rising wage inequality has been partly offset by a negatively correlated reduction in the inequality of the nonpecuniary returns to work, or whether changing inequality of nonwage returns has exacerbated the rise in wage inequality. That is, does the conventional wisdom about rising wage inequality overstate or understate the true extent of the change in overall inequality in the returns to work?

Very little research has even been conducted on changes in inequality of the pecuniary nonwage returns to work (but see Wolaver et al, 1996, and Farber, 1997). The complete absence of any research on changing inequality in nonpecuniary workplace characteristics is especially surprising given the number of possibilities for study. Here I concentrate most of the attention on the one aspect of work, the risk of workplace injury, that has probably received the greatest study by economists concerned with the cross-section relationship between wages and workplace amenities. ${ }^{1}$ But while this relationship has been extensively studied, no attention has been given to the changing inequality of the burden of injuries, nor to its relation to changing wage inequality. 
Examining the relation between the distribution of earnings and that of nonpecuniary aspects of work is an exercise in the study of implicit markets (Rosen, 1974). This literature has focused almost exclusively on measuring the market trade-off between price (earnings) and a particular disamenity. Here I concentrate on the distribution of the quantity of the amenities that workers consume. Under some reasonable assumptions the sample design used in most of the parts of this study allows me to generate estimates of the income elasticities describing the implicit markets for the workplace disamenities that I analyze.

I present evidence on the relationship of changing inequality in the burden of disamenities to changing inequality of earnings and examine how our perceptions of inequality are altered when we take into account the impact of workplace risks. Data on injuries in the United States in the 1980s and 1990s are studied and are then compared to data from the 1960s, a period with a different trend in earnings inequality. To check whether the underlying phenomenon is unique to the United States, I then offer some cursory evidence on it for the Netherlands for 1974-92. In order to examine whether the changing inequality in the burden of injury risks is an artifact of the data or is instead consistent with the theoretical rationale that I offer, I also analyze changes in the inequality of a second disamenity, the burden of work at undesirable times of the day. ${ }^{2}$ The results from all but the Dutch study are then used to infer the extent to which changes in the distribution of measured earnings understate or overstate changes in the distribution of returns to labor-market activities and to measure income elasticities of demand for labor-market disamenities.

\section{Theoretical Outline}

I consider here the assignment of amenities -- the matching of workers with heterogeneous tastes for a particular amenity with firms that have different costs of offering that amenity (as in 
Rosen, 1974). The worker/consumer i maximizes utility based on a unique set of indifference curves between money and the amenity, characterized by:

$$
\mathrm{U}_{\mathrm{i}}=\mathrm{U}_{\mathrm{i}}\left(\mathrm{W}_{\mathrm{i}}, \mathrm{D}_{\mathrm{i}} \mid \mathrm{E}_{\mathrm{i}}\right)
$$

where $\mathrm{W}$ is the wage rate that the worker can obtain, $\mathrm{D}$ is the extent of the disamenity, and $\mathrm{E}$ denotes the worker's (unobservable) full earnings that are a combination of W and D. (I abstract from any unearned income that workers might receive.) The worker's preferences are such that the implied indifference curves are upward-sloping in utility space defined over (W, D). As is standard, we assume no correlation of workers' preferences for risk and their full earnings. We can view employers as being differentially able to generate profits when they produce at a given $\mathrm{D}$. For a firm with labor as its only input the profit function is:

$$
\Pi_{j}=\Pi_{j}\left(W_{j}, D_{j}\right) \text {, }
$$

with the implied isoprofit curves sloping upward in W-D space at decreasing rates.

Equilibrium in the market for the disamenity is characterized by the matching of workers and firms in W-D space. The equilibria chosen by the low full-earnings Worker A and the high fullearnings Worker B are shown in Figure 1. Both face the same market-wide trade-off between wages and the disamenity, shown as the slope of $W_{0}$, but Worker $B$ could earn more, $W_{0 B}^{*}$, even at $D=0$, presumably because his/her bundle of skills (both measurable and unmeasurable) generates a higher return in the labor market. Since by definition the disamenity is an inferior good, Worker B's higher full earnings lead him/her to buy less of the disamenity, $D_{0 B}<D_{0 A}$, even though we assumed that the two workers have the same preferences for risk. Thus we will observe that more skilled workers are matched with firms that can reduce the disamenity more cheaply. This negative correlation of full 
Figure 1. Wages and Disamenities Under Changing Inequality

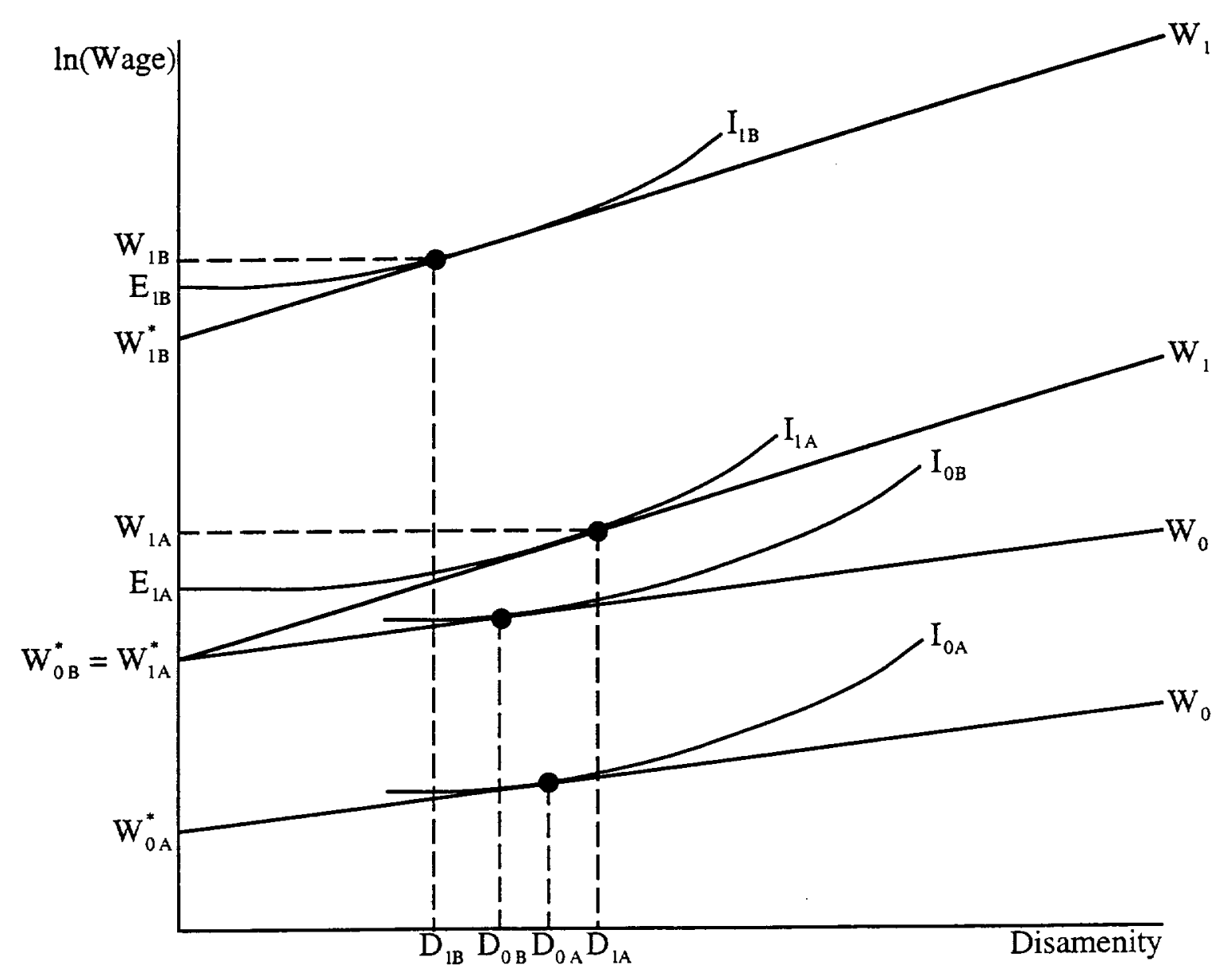


earnings and D through the income effect is what leads to the difficulties in measuring the slope of the locus $W_{0}$ in Figure 1 that has been noted by, inter alia, Brown (1980) and Hwang et al, (1992). ${ }^{3}$

The focus throughout this study is on the income effects generated by exogenous changes in full earnings. Assume that there is an exogenous shock that causes the relative full-earnings differential between Workers $A$ and $B$ to rise, even while their average full earnings increase. These changes are depicted in Figure 1 as a rise in Worker A's full earnings to the point that he/she would earn $W_{1 A}^{*}$ at $D=0$, and those of Worker $B$ to where he/she would earn $W_{1 B}^{*}$ at $D=0$. Because full earnings have risen generally, the slope of the W-D locus has risen, so that the market locus and is now represented by $W_{1}$. The income effects of rising full earnings generally force firms to compensate workers more for accepting riskier jobs. Although Worker A experiences a negative income effect that would lead to less of the disamenity being consumed, the rising return to accepting risk generates a price effect that leads him/her to accept more of the disamenity, a net move from $D_{0 A}$ to $D_{1 A}$. For Worker $B$, on the other hand, the income effect dominates the price effect, leading to less consumption of the disamenity, a net move from $\mathrm{D}_{0 \mathrm{~B}}$ to $\mathrm{D}_{\mathrm{lB}}$. In general, we should expect to observe that those workers whose earnings are falling (rising) relative to those of the average worker will also find their burden of the disamenity rising (falling) relative to that of the average worker.

Because of the possibly offsetting income and price effects we cannot be certain that an exogenous rise in the typical worker's full earnings will result in a decrease in D, any more than we can be sure that the long-run effect of higher real wages is a reduction in hours of labor supplied. The latter has happened over the past 100 years, even though rising real wages generate both income and substitution effects on hours of work. We might also expect that the effects of exogenous increases in full earnings will dominate the endogenous price effects that occur as workers seek to avoid risk, 
but that is not guaranteed. If, however, a rise in full earnings inequality is generated exogenously; if, as we typically assume, preferences are independent of full earnings; and if technical change in the ability of firms to remove disamenities is neutral across levels of workers' full earnings, then a rise in inequality in full earnings will be accompanied by a concomitant and related rise in the inequality of the burden of the disamenity. Under these assumptions the impacts of neutrally changing technology and of the changing price of the disamenity are differenced out of the effects on the assignment of the disamenity examined across workers and over time.

This analysis implicitly assumes that firms contract with individuals for specific packages of wages and disamenities. This is clearly not entirely correct. Some plants are characterized by collective bargaining over wages (and, as Stafford and Duncan, 1980, show, implicitly also over disamenities). This observation does not affect our conclusions so long as the risk preferences of the median union voter do not change relative to those of other workers as they experience changes in their relative full earnings. Probably more important, workplace disamenities have at least in part some aspect of a public good (Stafford, 1980). ${ }^{4}$ This characteristic generates lags in the response of the matching of workers and disamenities, since much of the process of equilibration must proceed through workers switching firms and new workers flowing toward different firms than they would have chosen before the exogenous shock to the distribution of full earnings, as is implied by the results in Kahn (1987). This means that any estimated income effects may not fully reflect long-run adjustments.

I have assumed that the technology of reducing the disamenity changes neutrally across workers with different full earnings, absent any reason to assume the existence of skill-biased change in firms' costs of reducing the disamenity. In the case of workplace injuries, for example, there is no 
a priori argument that might lead us to conclude that the ease of reducing injuries has changed differentially across employers classified by the skills of their workers. Also, it is difficult to construct empirical correlates of nonneutral technical changes in firms' abilities to reduce disamenities for workers of different skills. For the prediction of a positive relationship between the change in the inequality of the distribution of disamenities and rising earnings inequality to be reversed, we would need to argue that the costs of reducing injuries dropped most in firms that were low-skilled intensive.

Lacking any expectation of nonneutrality, I simply note that any inferences about changes in the distribution of earnings understate (overstate) the true rise in inequality that would have been generated by workers' behavior alone to the extent that technical change has reduced the costs of avoiding injuries more in low-skilled (high-skilled) intensive industries.

This discussion says nothing about the underlying sources of the changes in full earnings that generate changes in the inequality of observed earnings and amenities. Whether these changes in workers' full earnings ultimately come from skill-biased technological change in production generally, from greater international openness, from changes in labor-market institutions, or from some other sources, is irrelevant for the purposes of this study. All that is required here is that an exogenous shock occurs that generates widening differentials in measured earnings and an associated change in the distribution of amenities that is the focus of the empirical analysis.

\section{Constructing Data on Injuries and Wages}

Ideally we would examine the joint distribution of wages and the risk of injury with data linked as closely to individuals as is conceptually possible, presumably data on risks at each worker's place of employment. Such data are not available; nor, indeed, are data on workplace risks and wages for individual establishments. Instead, I am forced to combine time series describing industry- 
level workplace risks with time series of data on industry averages of wages. For many years the Bureau of Labor Statistics (BLS) has collected establishment data on the number of occupational illnesses and injuries (predominantly composed of the latter) that resulted in lost workdays. Since 1972 the data have been collected under explicit guidelines to ensure comparability across industries and over time. By the late 1970s this program of data collection had reached maturity, and these data are available through 1995. Information is also available on the average duration of these spells of lost workdays. I use data on the rate of injury, $\mathrm{INC}$ (idence), expressed per 100 employees; on the average duration of injuries (DUR); and on the fraction of total working time lost to workplace injuries $($ TOTINJ $=\mathrm{INC} \times$ DUR). The estimates presented in Section $\mathrm{V}$ describe the experience reflected in annual data from 1979-95, but because the duration data are not strictly comparable after 1991, many of the comparisons are made from 1979 to 1991 only. 5

The industry average injury data are available by three-and four-digit SIC category, a method of categorization that changed somewhat in 1983. Earnings data are available from the Current Population Survey's (CPS) Outgoing Rotation Groups. Earnings in each industry in each year are computed by weighting (by weekly hours) the weekly earnings of all persons with positive hours of work in the industry. (Topcoded earnings are multiplied by 1.5 in calculating this weighted average.) The difficulty is that the CPS data are classified by Census industry. Blithely merging data from the two methods of classification would guarantee mismatches in the data. To avoid this problem I exclude all observations for which the Census and SIC definitions did not match uniquely, all workers who were self-employed and all public employees. This process created an unbalanced panel of between 144 and 167 industries that contains information describing all industries in each year for which the Census and SIC definitions were the same at that time and in which at least 25 workers 
were sampled from the CPS. Results based on this panel would present problems, since the potential for changing interindustry differences in technology might affect our inferences about trends in inequality as the mix of industries changes over time. Accordingly, I further excluded industries to create a balanced panel of 134 small industries whose SIC and Census definitions were identical and unchanging over the entire seventeen-year period. ${ }^{6}$ The balanced panel consists of industries covering between 71 and 79 percent of private-sector employees in the CPS.

Table 1 shows the percentage distributions of employment by one-digit industry in the panel and in published establishment data. Because the Census and SIC industry definitions differ more from one another in nonmanufacturing than in manufacturing, the samples of industries on which the results here are based are necessarily weighted disproportionately toward manufacturing. Services are particularly underrepresented in the data used here, while wholesale and retail trade are represented in proportion to their importance in the economy. The nonrandomness of the sample selection may qualify the conclusions that I draw here. It is, however, dictated by the difficulty of matching data from two different classifications of industry and, most important, by the desire to have an unchanging set of industries in order to ensure comparability of the samples across years. These gains more than offset the slight (since three-fourths of all employees are represented) problems that may arise because the data are not fully representative by industry.

\section{Wage Inequality and Injury Inequality: The United States, 1979-95}

Most of the literature on changing earnings inequality has been able to use individual data, a luxury not possible in studying the burden of injuries. To make sure that the underlying rise in the inequality of earnings is reproduced at the industry level, I first calculate the weighted standard deviations of the logarithms of average weekly earnings by industry. This measure of dispersion 
Table 1. Percent Distribution of Workers, Panel and Actual, 1979, 1991 and 1995, by One-Digit Industry"

\begin{tabular}{|c|c|c|c|c|c|c|}
\hline & \multicolumn{2}{|c|}{1979} & \multicolumn{2}{|c|}{1991} & \multicolumn{2}{|c|}{1995} \\
\hline Industry & Panel & Actual & Panel & Actual & Panel & Actual \\
\hline Agriculture & 2.29 & 3.39 & 1.09 & 2.78 & 1.14 & 2.75 \\
\hline Mining & 1.84 & 1.25 & 1.23 & 0.75 & 1.11 & 0.58 \\
\hline Construction & 7.19 & 5.84 & 6.97 & 5.03 & 7.44 & 5.13 \\
\hline Manufacturing & 33.76 & 27.51 & 27.06 & 19.92 & 27.27 & 18.40 \\
\hline Transportation & 8.06 & 6.72 & 7.97 & 6.23 & 8.52 & 6.09 \\
\hline Wholesale & 5.04 & 6.83 & 5.11 & 6.58 & 4.56 & 6.34 \\
\hline Retail Trade & 20.69 & 19.58 & 23.36 & 20.87 & 22.05 & 21.05 \\
\hline Finance & 8.04 & 6.51 & 9.55 & 7.19 & 9.61 & 6.76 \\
\hline Services & 13.08 & 22.38 & 17.66 & 30.66 & 18.29 & 32.90 \\
\hline
\end{tabular}

${ }^{2}$ Calculated from the CPS samples and from Jacobs (1997) and BLS (various issues). 
increased from 0.284 to 0.341 between 1979 and 1995, with most of the change occurring between 1979 and 1982, and from 1994 to 1995 . The increases in dispersion in this sample between 1979 and 1987 are identical to what Bell and Freeman (1991) found for this period using a different set of industries (National Income and Product Account -- NIPA -- definitions). The results are quite consistent with evidence at the individual level that the 1980s saw a sharp increase in earnings inequality, an increase that slowed but did not reverse in the first half of the 1990s. The rise in inequality across the small industries in this sample is slightly less than half that of the rise in inequality among individual full-time male employees. Between 1979 and 1991 these changes were +0.026 and +0.076 , between 1979 and 1995 they were +0.057 and +0.119 .

To relate changing inequality in the burden of injuries to changing earnings inequality, simply calculating one-dimensional measures of dispersion does not suffice. We need to choose some measure of earnings inequality and examine how the distribution of injuries has varied across units of observation at various points of the earnings distribution. Remembering that the basic unit of observation here is necessarily the small industry, I sort the industries by their (weighted) average weekly earnings in each year, obtaining a ranking of these $W_{j}$ for the $j=1, \ldots, 134$ industries. (Note that nothing requires this ranking to remain unchanged over the years, although year-to-year changes will obviously be small.) I then compare the differences of means, $\bar{W}_{q^{t}}-\bar{W}_{q^{\prime} t}$, where the $q$ are quantiles, to differences in the means of each of injury incidence, duration, and the total injury rate across the same $q$ and q' quantiles of the distributions of industries sorted by wages. ${ }^{7}$ There is no obvious way to create quantiles; but since it is important to have at least a reasonably large number of industries in each group over which the means are calculated, I initially divide the sample into quartiles. Thus we are essentially asking whether there is comovement over time between differences in earnings 
inequality across quartiles and differences in the measures of industry injury outcomes defined over those same earnings quartiles.

Figure 2 shows the interquartile differences in the total rate of lost workdays due to workplace injuries across industries between 1979 and 1995. Both the differences between the top and lowest earnings quartiles, and between the third and lowest quartile, fall fairly steadily over this entire period, as well as during the subperiod 1979-91. These declines are quite drastic, to the point where, at the end of the period, the interquartile differences were actually negative: The total burden of injuries, which in the late 1970 s and early 1980 s was much higher in the higher-paid industries, was actually slightly lower there by the mid-1990s. These changing patterns provide very clear support for a supply-based view of the changing market for disamenities during this time of rising earnings inequality. Only the difference between the second and lowest quartile contradicts this view.

Figure 3 shows that the changing difference between the top quartile and the lowest earnings quartiles is not caused by correlated changing inequality in the duration of injuries. While there is some evidence of a decline in the difference in injury duration between the third and lowest quartiles, whether one looks at $1979-91$ or at the entire period the overall picture is one of no major changes. Figure 3 also shows that the surprising rise in the difference in total injuries rates between the two lowest quartiles is not due to a widening of differences in the duration component of the total injury burden, as there is essentially no trend in this interquartile difference. ${ }^{8}$

Unsurprisingly, given the results depicted in Figures 2 and 3, we find in Figure 4 that there were substantial declines in the interquartile differences in the incidence of injuries between industries in each of the upper quartiles and those in the bottom quartile. By the 1990s workers in industries in the upper half of the pay distribution faced a risk of injury that was below that facing workers in 
Figure 2. Difference in Total Injury Rate Over Lowest Earnings Quartile

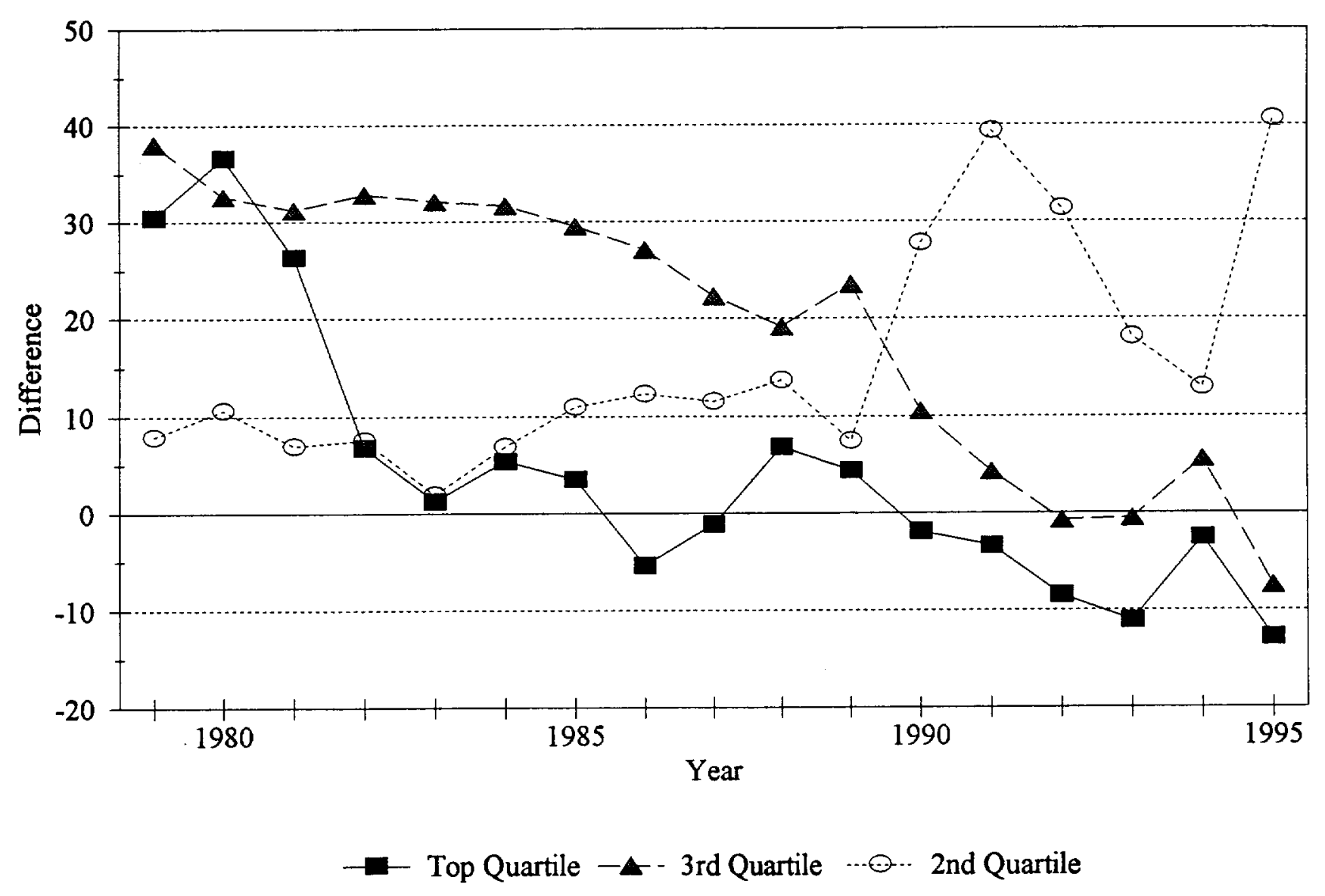


Figure 3. Difference in Injury Duration Over Lowest Earnings Quartile

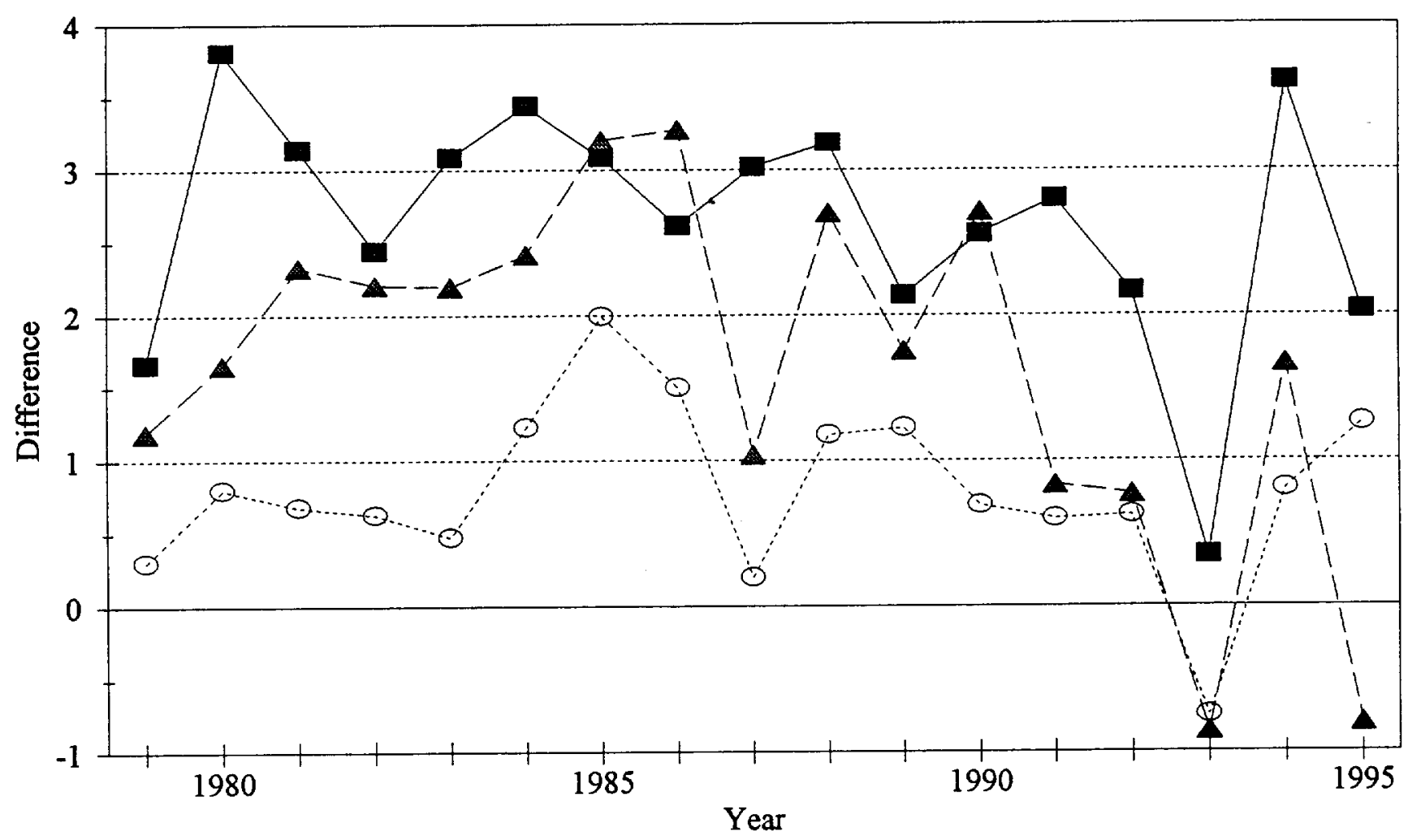

- - Top Quartile - - - 3rd Quartile $\cdots \odot-2$ 2nd Quartile 
Figure 4. Difference in Injury Incidence Over Lowest Earnings Quartile

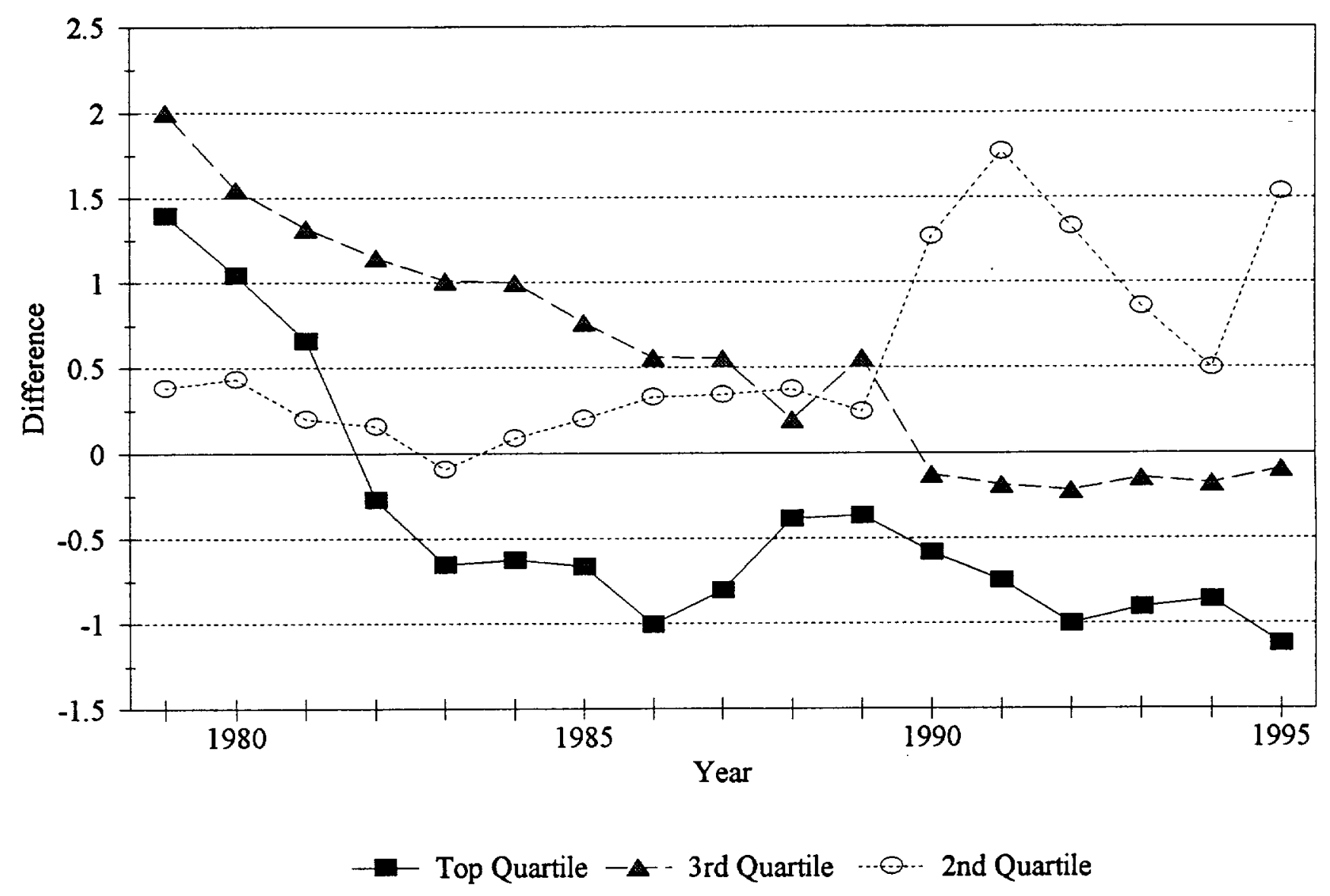


the lowest-paid quartile of industries. Similarly, after having been essentially constant for ten years the difference in the risk of injury between industries in the lowest two quartiles rose in the 1990s. Essentially all of the narrowing burden of injuries that accompanied the widening of earnings inequality across industries during this period resulted from the changing pattern of injury risks, not from any major changes in interindustry differences in injury duration. ${ }^{9}$ Neither this graph nor Figures 2 and 3 changes qualitatively when employment shares are used to weight the industries.

While the time-series patterns of the changing inequality of injuries by earnings quartile seem fairly clear, one wonders whether they are statistically significant. A quite stringent test, given the relatively few degrees of freedom into which the massive amounts of underlying data have been collapsed, is to estimate the bivariate regression:

$$
\left[\mathrm{INJ}_{\mathrm{q}}-\mathrm{INJ}_{1}\right]_{\mathrm{t}}=\alpha+\beta \mathrm{t} ; \mathrm{q}=2,3,4 ; \mathrm{t}=1979, \ldots, 1995,
$$

where the $\alpha$ and $\beta$ are parameters, and INJ is one of the injury measures. The estimates of the $\beta$ for each of the three injury measures, and for each of the three differences over the lowest quartile of industries sorted by earnings, are shown in Table 2 for the entire period 1979-95 and the subperiod 1979-91. The strongest result is that the declines in the differentials in total injuries and the incidence of injuries between the top and bottom earnings quartiles are statistically significant over the entire time period. Similarly, the decline in the incidence of injuries between the third and bottom quartiles is statistically significant. Beyond that, there are no significant trends in these interquartile differences. The best conclusion from this approach to summarizing the evidence in Figures $2-4$ is that the total burden of injuries and the risk of being injured fell in those industries where earnings rose most relative to those where earnings rose least. 
Table 2. Estimated Coefficients from (3)

Dependent Variable

Earnings Quartile

Top Third Second

1979-95

Total Injury

$\begin{array}{lll}-144.61 & -28.55 & 49.04\end{array}$

(70.49) (117.19) (73.02)

Duration

$\begin{array}{lll}-0.39 & 1.92 & 5.43\end{array}$

(4.71) (9.74) (3.55)

Incidence

$-14.43 \quad-10.43$

1.69

(1.82) (4.91) (3.48)

1979-91

Total Injury

$\begin{array}{ccc}-111.02 & 45.99 & -17.01 \\ (76.61) & (66.07) & (47.46)\end{array}$

Duration

2.48

$$
10.71
$$

6.04

(3.52)

(5.43)

(3.50)

Incidence

$\begin{array}{ccc}-14.21 & -10.82 & -0.66 \\ (1.57) & (4.02) & (2.50)\end{array}$

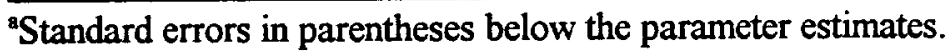


This discussion has focused on quartiles of the annual distributions of earnings because of the desire to conserve on degrees of freedom in a panel with only 134 units. To narrow the inquiry we can examine how changes in the injury statistics are correlated with changes in earnings inequality by decile. Using the same sorting of industries by measured earnings as before, I now consider instead differences in the injury statistics averaged over deciles rather than quartiles. In particular, I study differences in the injury outcomes between industries in the top decile of wages each year and those in the bottom decile.

The average differences in the three injury outcomes between industries in the top and bottom deciles of the distribution of earnings are shown for 1979-95 in Figure 5. The results confirm those in Figures 2-4: The differences in the total burden of injuries and in the incidence of injuries between industries in these extreme deciles fell sharply (and by the end of the period were negative); the difference in duration of injuries hardly changed over this time period. Bivariate regressions like those based on (3) confirm the impressions given by the series in Figure 5: When we base the regressions on deciles of the distribution of industries by earnings, the estimate of $\beta$ for TOTINJ becomes -4.66 (standard error of 0.405$)$; that for duration becomes $-0.059($ s.e. $=0.067)$; and that for incidence $-0.232(s . e .=0.029)$. There are strongly significant negative trends in the correlations of interindustry inequality in earnings and interindustry inequality in the total burden and incidence of injuries. As one would expect from the theory, the trends across the extreme deciles are stronger than those in the interquartile differences shown in Figures 2 and 4.

The correlation of the changing dispersion of wage inequality and the changing inequality of risk of industrial injury that is demonstrated in Figures 2-5 and Table 2 may be the result in part of changing interindustry differences in the ability of firms to reduce disamenities for workers of different 
Figure 5. 90-10 Differences in Injury Measures, 1979-95

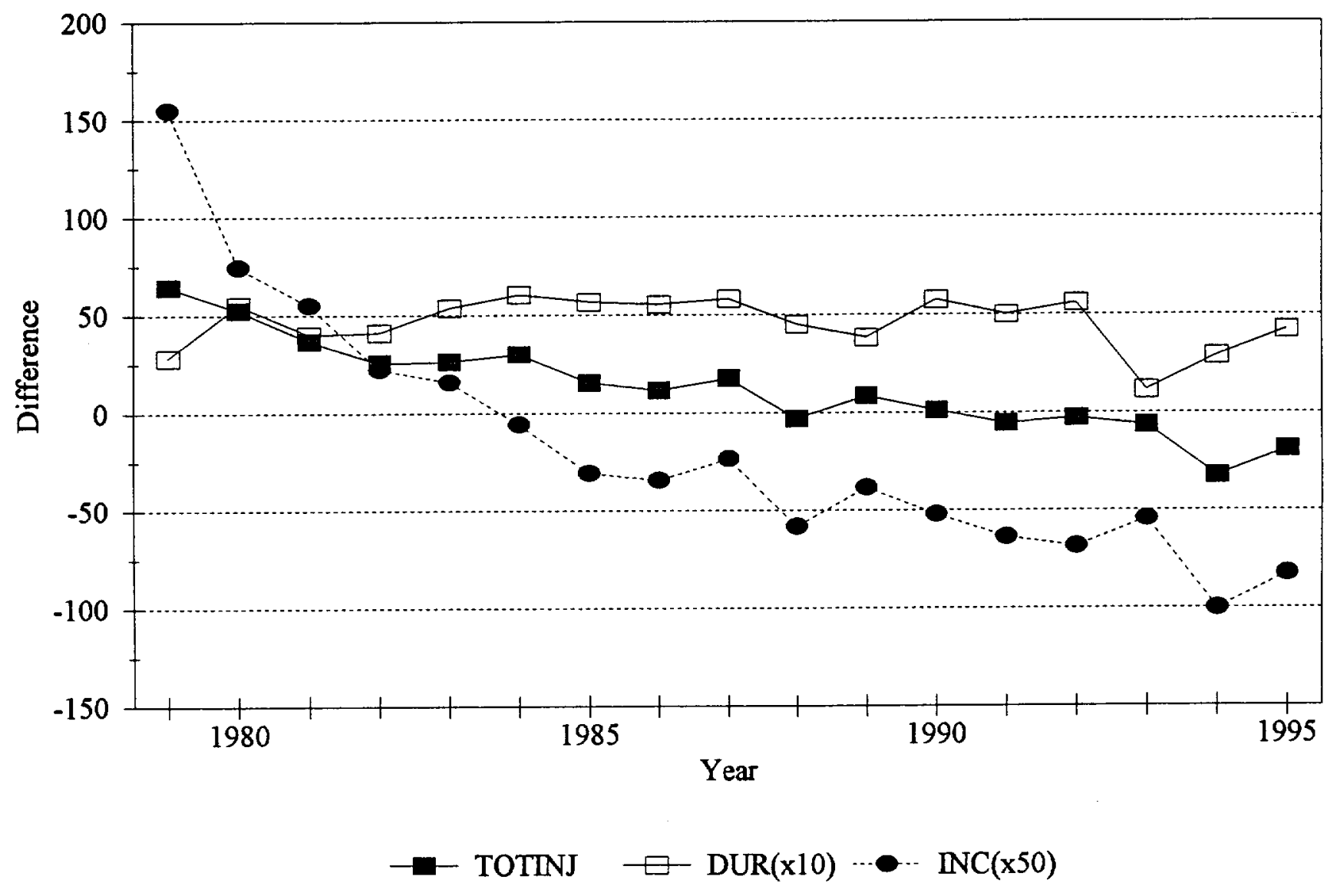


full earnings. While we cannot fully account for this potential problem, one step toward abstracting from it can be taken if we define the quartiles (deciles) of the earnings distribution by averages of earnings over the entire period 1979-95, so that the same industries are included in each quartile (decile) in each year. ${ }^{10}$ Between 1979 and 1995 the difference in earnings between industries in which average earnings over the entire period were in the top quartile (decile) over those in the bottom quartile (decile) increased by $0.138(0.114) \log$ points: The expansion of earnings inequality was clearly not a reflection of a changing industry mix.

Figure 6 presents comparisons of $\left[\mathbb{N J}_{\mathbf{q}}-\mathrm{INJ}_{1}\right]$, while Figure 7 presents the $90-10$ differences comparable to those in Figure 5. The conclusions do not change greatly from those in the earlier figures: There is a general decline between 1979 and 1995 in the inter-(earnings) quartile difference in the burden of injuries, a decline that was generated entirely by the declining relative risk of injury faced by workers in industries that were in the upper quartile of earnings. ${ }^{11}$ (The rise in TOTINJ after 1991 is entirely due to a one-time rise in measured duration, no doubt due to the change in how the indicator is calculated.) A similar decline between 1979 and 1991 is observed between industries in the top and bottom deciles of the earnings distribution. ${ }^{12}$

Another related concern is that the results in this section may be dominated by very rapid changes that occurred in the early 1980s as a result of the increased exposure of American durable manufacturing industries to foreign competition and the sharp reductions in labor demand that occurred in those industries. To examine whether the results here merely reflect the decline of the durable goods sector, I recalculate the measures of earnings and injury statistics by earnings quantile excluding all durable goods industries. Among the remaining industries in the sample, in 1979 average earnings in the upper quartile were 0.65 log points above those in the lowest quartile, while 
Figure 6. Interquartile Differences in Injuries, Constant Industry Mix

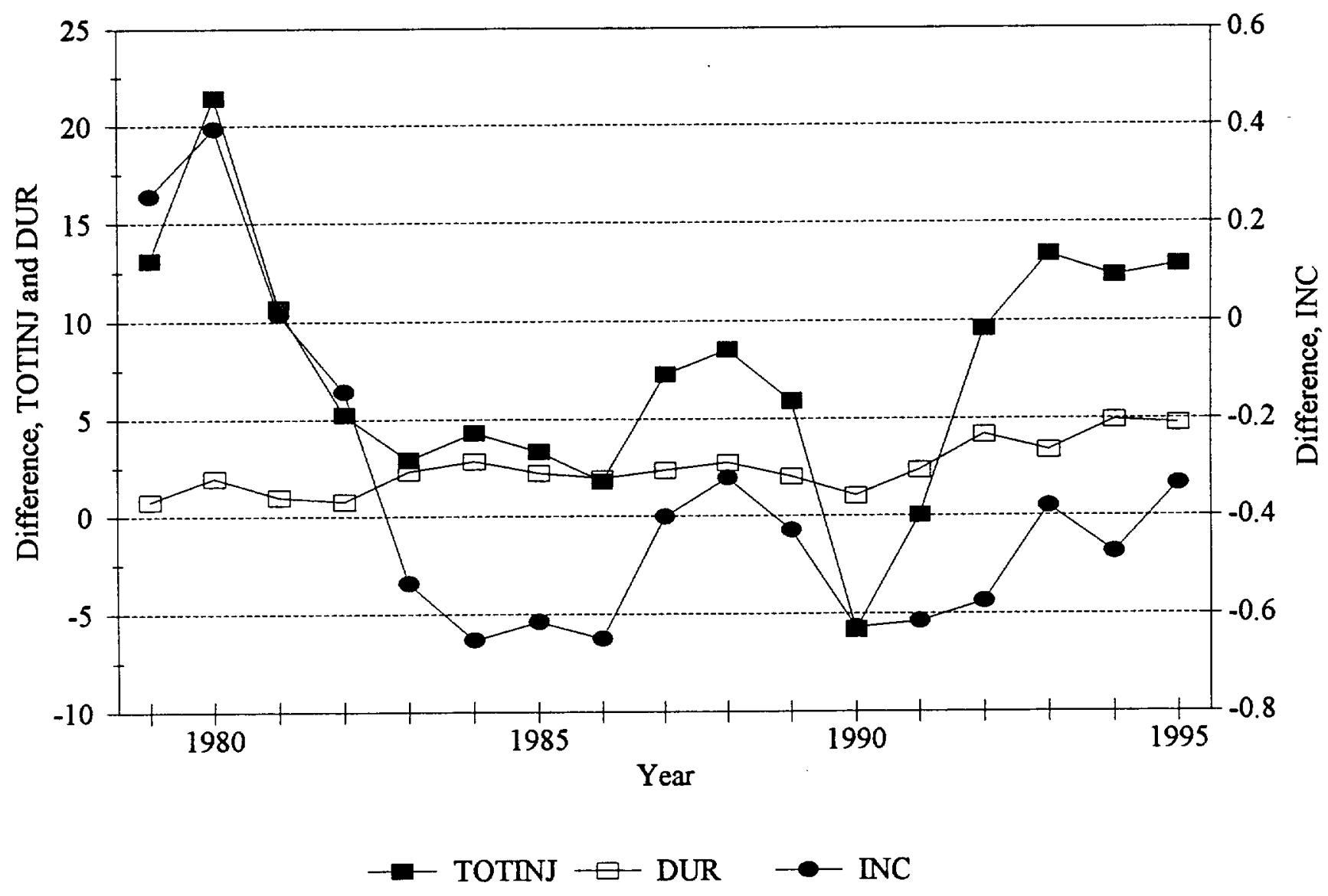


Figure 7. 90-10 Differences

in Injuries, Constant Industry Mix

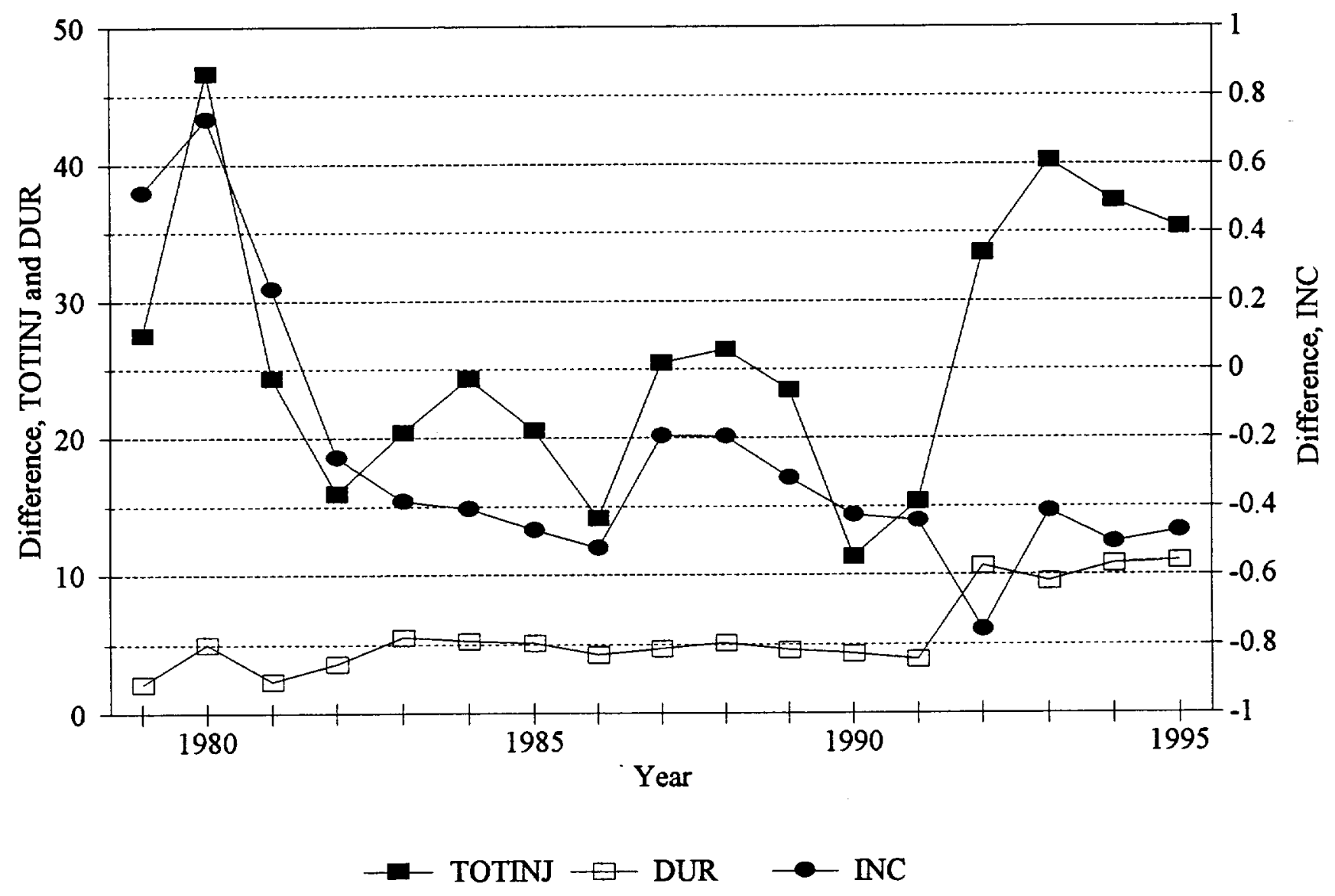


INC exceeded that in the lowest quartile by 0.77 lost workday injuries per 100 employees. In 1995 the difference in average earnings had risen to $0.77 \mathrm{log}$ points, while the difference in INC between the top and bottom quartiles of industries sorted by earnings was -0.60 . Clearly, the changes presented in Figures 2-4 are not due to the changing nature of durable manufacturing.

\section{Is the Phenomenon Time-Specific? The United States, 1960-70}

The results in the previous section are strikingly supportive of the notion that changing inequality in the distribution of disamenities parallels that in the distribution of earnings, suggesting that workers' behavior is more important than any nonneutral (across skills) technological changes in the prevention of industrial injuries that may have occurred. While the results are statistically significant and economically important, in a real sense they are based on only one observation, the period of widening earnings inequality that occurred in one time period (the 1980s and 1990s) in one country (the United States). To examine the predictive value of the framework constructed in Section II, in this section I study the same phenomenon at a time and place where earnings inequality was not widening. Under the assumptions made in Section II, we should observe that the burden of injuries becomes increasingly concentrated among workers in high-wage industries where and when interindustry earnings differentials narrow.

As noted in Section III, today's U.S. injury statistics are based on a survey initiated only in 1972; but an internally consistent series of data on the incidence of injuries is available from 1958 through 1970 for roughly two-digit industries in the U.S. Because 1958 was a year of a very deep, but short recession, I compare earnings inequality and the incidence of injuries in 1960 to that in 1970. I examine annual earnings per full-time-equivalent employee in the 46 industries that are 
defined identically in these two years (NIPA data) and compare them to the injury data (from U.S. Department of Labor, Handbook, 1973).

It is now well known that earnings differences among individuals stayed roughly constant in the United States between 1960 and 1970, after a period of substantial narrowing (Goldin and Margo, 1992; Juhn et al, 1993). Consider, however, the change in earnings inequality at the level of two-digit industries over this decade. The logarithms of average earnings among industries in the top and bottom quartiles of earnings are shown in the first two rows of Table 3 . The final number in the third column of this first part of the Table is $\Delta^{2}$, the double difference depicting the change in earnings inequality across quartiles between 1960 and 1970. This decade saw a decline of 11 log points in the inequality of earnings across these industry quartiles, a decline that is also reflected for this period in other measures of interindustry wage dispersion (Bell and Freeman, 1991, Table 1). The first column in the second set of rows in the Table presents the average incidence of workplace injuries (per 100 employees) in industries in the top quartile of the earnings distribution in each of 1960 and 1970; the second column presents the same data for industries in the bottom quartile, while the third column presents $\left[\mathbb{N C}_{4}-\mathbb{I N C}_{1}\right]$. The final number in the third column of this part of the table is $\Delta^{2} \mathrm{INC}$, the double difference in $\mathrm{NC}$ across quartiles of the distribution of earnings over this decade. Its positive sign demonstrates that the incidence of workplace injuries increased in the 1960 s especially rapidly in high-wage industries.

The only difficulty with the comparison of the results for the 1960 s to those from the 1980 s$90 \mathrm{~s}$ is that the data in the previous Section are at the three- and four-digit industry level: Perhaps the same phenomenon is not observable at the two-digit industry level during this later period. The bottom half of Table 3 presents the same results as the top half, but calculated for 1979 and 1995 
Table 3. The Incidence of Injuries, Larger Industries 1960-70, 1979-95

\section{Top Earnings \\ Quartile}

Ln(Earnings): 1960

1970

$\Delta^{2}$

Incidence of Injury:

1960

1970

$\Delta^{2}$

n(Earnings):

1979

1995

$\Delta^{2}$

Incidence of Injury:

1979

1995

8.765

9.195

9.475

12.633

5.837

6.645

4.996

2.120
11.983

12.858

8.179

8.691

0.504

$-0.082$

$\mathrm{N}=42$
5.267

5.979

0.570

0.666

0.096

3.652

3.559
$-0.225$

2.283
$\Delta^{2}$
1.344

$-1.439$

$-2.783$ 
using as many of the two-digit industries that were defined the same during this period as during the 1960s. The results are qualitatively identical to those of the previous section. Earnings inequality increased at this level of disaggregation, and the incidence of injuries fell disproportionately in highwage industries.

The absolute increase in incidence during the 1960s may be the spurious result of increases in the propensity to report injuries, but it is difficult to argue that changes in the survey led to increased reporting mainly in high-wage industries. It seems even more difficult to claim that somehow there were skill biases in the changing technology of reducing injuries in the 1960s that went in the opposite direction from such biases in the 1980s and 1990s. Assuming that this is not the case, the results here mirror those presented in the previous section: Changing inequality in the distribution of earnings understates the overall change in the inequality of labor-market outcomes.

\section{Is the Phenomenon Country-Specific? Dutch Industrial Sectors, 1974-92}

Significant economywide changes in earnings inequality are necessarily observed only at fairly low-frequencies. Thus in a very real sense the analysis in each of the last two sections, like the massive literature on earnings inequality, still only presents two realizations of the process described in Section II. To examine the issue further we need to obtain another realization of the relationship between changing inequality of full earnings and the changing burden of workplace injuries. Sufficiently long time series of industry data on injuries are apparently quite rare outside the United States. Fortunately, such data are kept by the Netherlands Central Statistical Office, and I use these in another test of the underlying phenomenon.

The data cover all major sectors from 1974-92 except mining (which in the Netherlands is tiny). Earnings are measured as total compensation in the industry divided by the number of 
employees. INC is calculated as the number of workplace accidents reported in the sector divided by total sectoral employment. With only eight sectors I cannot examine interquantile differences in injury rates across industries sorted by earnings level. That means that we cannot identify the pure income effects that are available when we have sufficient information to measure differences over time and across positions in the distributions of earnings. Instead, I calculate the trends in INC and in the logarithm of compensation per employee. If rising inequality in full earnings generated changes in earnings inequality and in the burden of injuries, we should observe that the trends in INC should be most positive (least negative) in those industries where the trend in compensation is smallest. This exercise does not sweep out the price effects generated by a change in the wage-risk locus as economywide earnings rise, but it does at least allow us to discover whether the net impact on the allocation of risk (of injury) is dominated by the income effect.

Table 4 shows the results of estimating the trends in compensation per worker and in INC for each of the eight major Dutch sectors. Were there no interindustry differences in the trends in compensation, we could not expect to observe any significant relationship between changes in compensation and changes in the burden of injuries. In fact, the first column of Table 4 shows substantial changes in relative earnings over this period, with the difference between earnings growth in the sectors with the largest and smallest trends implying a change of 24 percent in relative compensation over the eighteen years. There are also substantial and significant intersectoral differences in the (mostly negative) trends in $\mathrm{INC}$.

The unweighted Pearson correlation between the trend coefficients describing compensation per worker and $\mathrm{INC}$ is $-0.42(\mathrm{p}=.30$ ). With so few sectors (of very different sizes) weighting the observations may be more important than in the results of the previous sections, where it had no 
Table 4. Trends in Injury Rates and Compensation, Dutch Industry, 1974-92

\begin{tabular}{|c|c|c|c|}
\hline Sector: & $\begin{array}{r}\text { Tre } \\
\text { Injury Rate }\end{array}$ & $\begin{array}{l}\text { nd in: } \\
\ln \text { (Earnings) }\end{array}$ & $\begin{array}{l}\text { Employment } \\
\text { Share }\end{array}$ \\
\hline Agriculture & $\begin{array}{l}-.954 \\
(.159)\end{array}$ & $\begin{array}{l}.036 \\
(.004)\end{array}$ & .021 \\
\hline Manufacturing & $\begin{array}{r}-1.137 \\
(.075)\end{array}$ & $\begin{array}{c}.043 \\
(.003)\end{array}$ & .269 \\
\hline Public Utilities & $\begin{array}{l}-.048 \\
(.011)\end{array}$ & $\begin{array}{l}.031 \\
(.003)\end{array}$ & .013 \\
\hline Construction & $\begin{array}{r}-1.410 \\
(.196)\end{array}$ & $\begin{array}{c}.041 \\
(.003)\end{array}$ & .100 \\
\hline Trade & $\begin{array}{l}-.423 \\
(.029)\end{array}$ & $\begin{array}{l}.038 \\
(.004)\end{array}$ & .207 \\
\hline Transportation & $\begin{array}{l}-.849 \\
(.092)\end{array}$ & $\begin{array}{l}.037 \\
(.003)\end{array}$ & .086 \\
\hline Banking & $\begin{array}{l}-.220 \\
(.136)\end{array}$ & $\begin{array}{c}.045 \\
(.003)\end{array}$ & .048 \\
\hline Other & $\begin{array}{c}.008 \\
(.032)\end{array}$ & $\begin{array}{l}.036 \\
(.005)\end{array}$ & .255 \\
\hline $\begin{array}{l}\text { Correlation: } \\
\text { Unweighted } \\
\text { Weighted }\end{array}$ & & $\begin{array}{l}-0.417 \\
-0.697\end{array}$ & \\
\hline
\end{tabular}


substantial effects. When we weight by average sectoral employment over 1974-92 the Pearson correlation coefficient of these trend terms becomes $-0.70 \quad(p=.05)$. Given the high level of industrial aggregation, these correlations can be interpreted as providing significant evidence that, in those sectors where compensation per worker was rising most rapidly in the Netherlands, the rate of industrial injuries was falling most rapidly.

\section{Another Workplace Disamenity - Evening and Night Work}

The theoretical discussion in Section II was in no way specific to the particular disamenity, workplace injuries, that I have discussed thus far. While injuries are the disamenity on which the greatest research interest has focused, the argument should apply to any nonpecuniary aspect of work. I view diumal variation in the timing of work as an amenity: There are more and less desirable times to be at work; employers have differential costs of offering employment at different times of the day, and cross-section evidence for the U.S. and Germany suggests that workers with low full earnings are disproportionately likely to work evenings and/or nights (Hamermesh, 1996a). Casual evidence; the existence of premia for evening and night work in union contracts in the United States and elsewhere; and a smattering of formal empirical studies (Kostiuk, 1990; Shapiro, 1995; Schumacher and Hirsch, 1997) suggest that at the equilibrium in the market for this aspect of work a premium of between 10 and 25 percent is paid in the United States, also implying that at the margin it is a disamenity. That being the case, so long as offers of work timing change neutrally across workers with differing full earnings, we should expect that shocks that widen the distribution of full earnings will also widen the distribution of the disamenity, evening and night work.

In 1973 and 1991 BLS collected information on workers' starting and ending times on their main jobs as part of the May CPS Supplements. I take samples from these two years and concentrate 
on the weekly earnings of all full-time workers. ${ }^{13}$ The samples are quite large -- nearly 20,000 men and 12,000 women with complete data in 1973, around 6000 men and 4000 women in the 1991 sample -- so that there are sufficient observations to focus on differences in outcomes between workers in the top and bottom deciles of the distributions of weekly earnings. There are a variety of ways of looking at changes in work timing. Here I use the CPS information on work starting and ending times and calculate for each worker first whether he or she was at work at each hour of the day, then the fraction of the workday accounted for by work at each hour. These are then averaged within deciles of the distribution of weekly earnings, and the ratio of the average fraction of work accounted for in the top decile by work at hour $t$ is divided by the fraction accounted for by work at $\mathrm{t}$ within the bottom decile. ${ }^{14}$ This ratio is then differenced between 1991 and 1973. Expressed algebraically I thus calculate:

(4) $\Delta_{s}^{2}=\left[F_{s 91}^{\operatorname{top}} / F_{s 91}^{\text {bot }}\right]-\left[F_{s 73}^{\operatorname{cop}} / F_{s 73}^{\text {bot }}\right]$,

where $\mathrm{s}$ is some hour of the day, and $\mathrm{F}$ is the average fraction of work performed at hour $\mathrm{s}$.

Since the usual calculation in the literature on changing earnings inequality is of differentials between workers at the $90^{\text {th }}$ and $10^{\text {th }}$ percentage points of the distributions, it is worth checking whether the standard conclusions hold when we examine changes in relative averages of earnings within the top and bottom deciles. For full-time male workers the ratio of earnings in the top decile rose between 1973 and 1991 from 5.61 times that of the average in the bottom decile to 7.60. Among full-time female workers the ratio rose from 4.90 to 5.92 . The results thus parallel the usual findings for workers at particular points of the earnings distribution: Earnings inequality increased over this period in the United States, but especially so among men. 
Figure 8 shows the calculations in (4) for men and women for 1991 compared to 1973. Among men there is clear evidence of the same result that we found for injuries: Comparing 1973 to 1991 the burden of work at undesirable times (evenings -- 8PM through 11PM; and nights -midnight through 6AM) was increasingly borne by workers in the bottom decile of the earnings distribution relative to those in the top earnings decile. The same thing is true of evening work among women. Only night work among women was not redistributed in this way. That the evidence is weaker for women is the perhaps unsurprising result of the lesser increase in earnings inequality that occurred among women during this period. Overall the results on this disamenity show that the impact of rising inequality in full earnings dominated the changes in the market for this particular workplace amenity, just as it did in the market for injury risks.

\section{Impacts on Measured Inequality, and Income Elasticities of Demand}

The evidence shows very clearly that the changing inequality of two nonmonetary aspects of work in the United States, workplace injuries and undesirable work schedules, changed during the 1980s and 1990s in ways consistent with supply forces, particularly income effects, being the dominant cause. This is interesting, for it means that popular and academic discussions of changing inequality, concentrating as they have on observed earnings, have understated the extent of the rise in dispersion of the returns to work that occurred in the United States between the 1970s and the mid-1990s. Obversely, the same explanation is sufficient to describe the relation between the incidence of workplace injuries and the narrowing of earnings differences that occurred during the 1960s. These considerations suggest that changes in measures of inequality that are based on pecuniary outcomes alone have understated the absolute changes in economic inequality in recent American economic history. 
Figure 8. 90-10 Differences in Work

Timing, 1991 over 1973

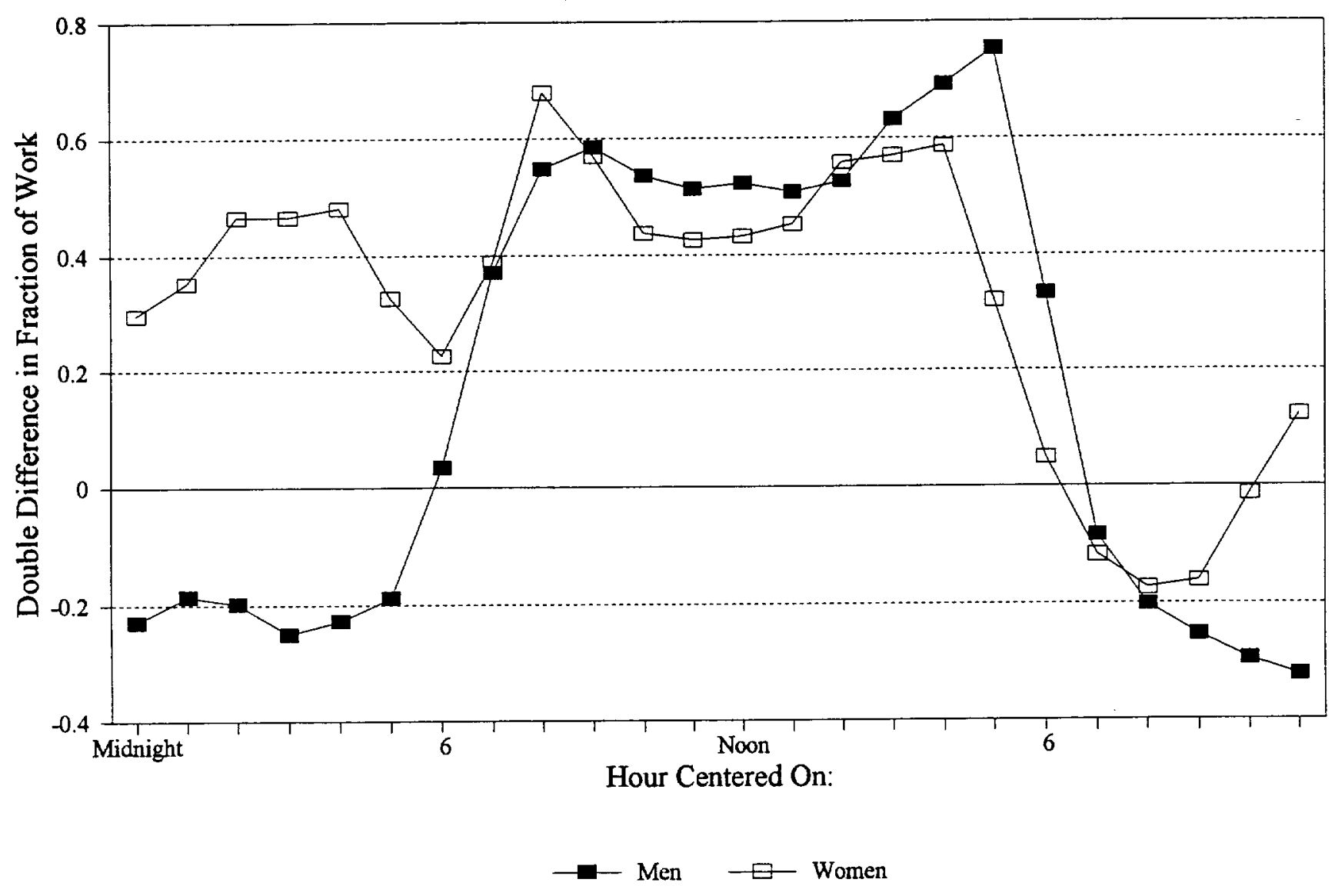


Since changes in earnings inequality are calculated on a different metric from changes in the burdens of injuries and of evening/night work, we need to devise some way to calculate the monetary equivalents of the measures of the disamenities if we are to devise measures of (levels and changes in) the inequality of full-earnings. We would like to measure changes in the differences in the full eamings, $E$ in Figure 1, that an individual would receive at the same indifference level but with $\mathrm{D}=0$. These of course are unobservable; but we can bracket the changes in them as being above the change in the dispersion of observed earnings, $\mathrm{W}$, and below that in $\mathrm{W}^{*}$, the earnings a particular worker would obtain if he/she enjoyed $\mathrm{W}^{*}$ at the current trade-off between wages and disamenities.

For each industry $i$ in year $t$ of the sample of industries from 1979-95 I calculate one measure of $\mathrm{W}^{*}$ based on workplace injuries as:

(5a) $\mathrm{W}_{\mathrm{it}}^{*}=\mathrm{W}_{\mathrm{it}} \exp \left\{-\boldsymbol{\gamma} \cdot \mathrm{TOTINJ}_{\mathrm{it}}\right\}$,

where $\gamma$ is the impact of one additional expected workday lost to injuries per 100 worker-years. I assume that $\gamma=0.0012$, based on the estimates in Hamermesh and Wolfe (1990) of a reduced-form earnings equation that included the total days lost to injuries per 100 workers (TOTINJ). The size of the impact of the changing inequality in the burden of injuries depends on both the change in the distribution of that burden and on the estimate of $\gamma$. As a check on the validity of the calculation in (5a) I thus also generate an alternative measure of $W^{*}$ for each observation:

$$
\mathrm{W}_{\mathrm{it}}^{*}=\mathrm{W}_{\mathrm{it}} \exp \left\{-\boldsymbol{\gamma}^{\prime} \cdot \mathrm{NC}_{\mathrm{it}}\right\} \text {. }
$$

Based on estimates of an earnings equation that included the risk of lost-workday injuries (Hersch, 1998), I assume $\gamma^{\prime}=0.013$

The calculations of the various measures of $\mathrm{W}^{*}$ rest on the assumption that each (representative) worker's observed earnings include compensation for the burden of the disamenity 
(in this case, workplace injuries). To remove this part of observed earnings -- to create earnings measures that reflect what would be observed if each worker bore the same risk of workplace injury -- we subtract for each observation the monetary equivalent of that risk. There would be no adjustment for a worker in a (hypothetical) perfectly safe industry. The linear adjustments in (5a) and (5b) overstate the adjustments to measured earnings required to obtain the full earnings of each riskaverse worker. In a time of widening inequality, with lower full-earnings workers bearing an increasing relative burden of the risk of injury, this means that these monetary adjustments overstate the extent to which growth in the inequality of $W^{*}$ exceeds growth in the inequality of measured earnings. The direction of the difference in changes in the measures of inequality is correct in this calculation, but we necessarily can only provide an upper bound to the growth in inequality of full earnings. ${ }^{15}$

The first column of the upper part of Table 5 shows estimates of the top-bottom quartile differences, and the interdecile differences in the logarithms of earnings across industries for $t=1979$ and 1995 , but also for $t=1991$ because of the possibility that the changes in the construction of the duration data in 1992 might have affected subsequent comparisons of inequality in the $W^{*}$ based on (5a). I then present the estimates of the interquantile differences in the measures of $W^{*}$, earnings adjusted for the disamenity value of the workplace injuries occurring in those industries that have been sorted by quantiles of the earnings distribution. The lower part of the upper panel in Table 5 lists the changes (in logarithmic terms) between 1979 and each of 1991 and 1995 for the same three series for each comparison across quantiles. The upper bounds to the rise in full-earnings inequality exceed the lower bounds (based on $\mathrm{W}$ ) by amounts that suggest that earnings measures alone may understate the growth in the inequality of returns to work by as much as 30 percent ( 4 percentage 
Table 5. Differences in In(Earnings), Unadjusted, and Adjusted for Injuries, 1979-95, and 1960-70

Top-Bottom Quartile

$\mathbf{w}$

W HW $^{\text {Adjustment: }}$

Year

1979

1991

1995

0.594

0.575

0.668

0.708

0.709

$\mathbf{W}$

0.064

0.093

0.084

0.587

0.671

0.719

Change (log points)

1979-91

W

90-10

HW $^{\text {Adjustment: }}$

HW

$\mathbf{H}$

1979-91

1979-95
0.115
0.133
0.132
0.138
0.189
0.175

0.780

0.898

0.955 
points). Accounting for this one important nonpecuniary characteristic of work alters our perceptions of changing inequality substantially.

The bottom panel of Table 5 presents similar calculations for $1960-1970$, based on the results in Table 3 and on the adjustment in (5b) that produces $\mathrm{W}^{*}$. (Only that adjustment is usable, because only the injury measure INC is available in the data from 1960-70.) The adjustment suggests that the decline in inequality in $\mathrm{W}^{*}$ was larger than is shown by the decline in the inequality of measured earnings. The differences between the changes in inequality and $\mathrm{W}$ and those in $\mathrm{W}^{*}$ are very similar to those shown in the upper part of the panel for 1979-95, lending additional credence to this approach to bounding changes in the inequality of full earnings.

Just as with the calculations of earnings inequality adjusted for the changing burden of injuries, we can use a similar approach to adjust earnings for the changing distribution of work timing between 1973 and 1991, and thus generate an upper bound measure of the change in inequality of full earnings. Unfortunately, the only available information on the market price of the disamenity of work timing defines it as working on evening or night shifts. While (as I have shown, Hamermesh, 1996b) the majority of people working evenings or nights do most of their work during the day, the available evidence requires that I define the disamenity here as working a substantial number of hours between 8PM and 6AM. I thus assume that any worker who was at work for at least four hours at these times of day experienced the disamenity, working evenings or nights (EVENITE). ${ }^{16}$ (Note too that, while we would like to use a measure of how much workers are paid for work at different times of the day, we only observe their weekly earnings.) The adjusted earnings of each worker $i$ in year $t$ are calculated as:

$$
\mathrm{W}_{\mathrm{it}}^{*}=\mathrm{W}_{\mathrm{i}} \exp \left\{-\theta \cdot \text { EVENITE }_{\mathrm{i}}\right\} .
$$


To provide an upper bound to changing inequality in full earnings I value this disamenity using an upper-bound estimate of the average shift premium in the United States (Shapiro, 1995) that suggests $\theta=0.25$. I expect that rising inequality in the distribution of evening/night work will have a much smaller effect on changes in the distribution of full earnings than did changes in the distribution of injury risks: Unlike the risk of injury, which can reasonably be viewed as confronting all, or at least most workers, working evenings/nights is experienced by relatively few workers; and the pain of working evenings or nights is probably generally much less than the pain of most workplace injuries.

Table 6 shows the interdecile ratios of actual earnings and of the calculation of $\mathrm{W}^{*}$ based on the adjustment in (6) for differences in the timing of work. The upper part presents the calculations for full-time male employees, while the bottom part shows the same calculations for full-time female workers. The rise in inequality between 1973 and 1991 implied by the upper bound is slightly greater for men than is the rise in actual earnings inequality, but as expected the difference is much smaller than in the calculations that accounted for the changing distribution of industrial accidents. For women this calculation indicates that, if anything, accounting for the changing timing of work leads us to infer that full-earnings inequality did not rise as much as is indicated by changes in differences in actual earnings. Figure 8 showed that, while evening work became slightly less equally distributed among women during this period, the burden of night work became more equal, so that the lack of much effect is unsurprising.

Under the assumptions that I have made the double differences in the measures of earnings and of the earnings-sorted disamenities can be used to calculate the income elasticities of demand for the particular amenities on which this study focuses. I stress that this does not solve the problem of 
Table 6. 90-10 In (Earnings) Differences, Unadjusted, and Adjusted for Evening/Night Work, Full-Time Workers, 1973-91

\begin{tabular}{|c|c|c|}
\hline & $\mathbf{W}$ & $W^{\star}(\theta=.25)$ \\
\hline Year & & MEN \\
\hline 1973 & 1.724 & 1.734 \\
\hline 1991 & 2.028 & 2.049 \\
\hline & Chang & g points), 1973-91 \\
\hline & 0.304 & 0.315 \\
\hline & & WOMEN \\
\hline 1973 & 1.590 & 1.596 \\
\hline 1991 & 1.778 & 1.780 \\
\hline & Chang & g points), 1973-91 \\
\hline & 0.188 & 0.185 \\
\hline
\end{tabular}


identifying the major structural parameters of interest, namely those characterizing the preferences of workers toward risk and employers' differential abilities to reduce those risks; but it does take a step in that direction by identifying under simplifying assumptions (skill-neutral change in the technology of reducing risks, and independence of risk preferences and full incomes) one supply-side response to an exogenous shock. We cannot provide a single estimate of these income elasticities, since we cannot measure the change in full earnings by quantile of their distribution; but we can bracket the income elasticity, $\Delta^{2} \mathrm{D} / \mathrm{D} / \Delta^{2} \mathrm{E} / \mathrm{E}$, as:

$$
\left|\Delta^{2} \mathrm{D} / \mathrm{D} / \Delta^{2} \mathrm{~W}^{*} / \mathrm{W}^{*}\right| \leq\left|\Delta^{2} \mathrm{D} / \mathrm{D} / \Delta^{2} \mathrm{E} / \mathrm{E}\right| \leq\left|\Delta^{2} \mathrm{D} / \mathrm{D} / \Delta^{2} \mathrm{~W} / \mathrm{W}\right|,
$$

where, as noted above, $\Delta^{2}$ here denotes the difference in an amenity or an earnings measure across earnings quantiles and over time. Thus the overadjustment in $\mathrm{W}^{*}$ and the observed measures of actual earnings provide the bases for lower and upper bounds to the true measure of the income elasticities of demand for these amenities under our assumptions about technology and independence of risk preferences and full earnings.

Table 7 presents the estimates of the upper and lower bounds to the income elasticities of demand for the workplace disamenities whose changing inequality was examined in the previous sections. Except for the changing timing of women's work, the other income elasticities are all highly negative. The elasticities are larger (in absolute value) in the 1979-95 data on injuries than in the 1960-70 data, because the greater level of aggregation in the latter data set masks part of the variation in the response of the demand for this amenity to differences in full earnings. Even in those data, however, amenities in the workplace appear to be a luxury good. 
Table 7. Income Elasticities of Demand for Disamenities

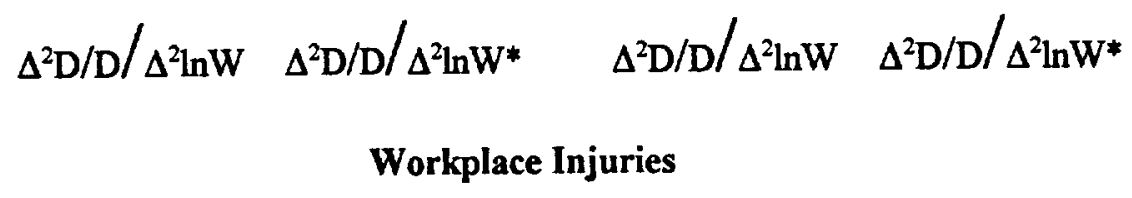

1979-91

1979-95

Based on Quartiles of 134 3-digit Industries

$\begin{array}{lcccc}\text { Total Lost Workdays } & -4.65 & -3.20 & -1.47 & -1.27 \\ \text { Incidence of Injury } & -5.69 & -4.35 & -2.97 & -2.61 \\ & & \text { Based on Deciles of } 134 & \text { 3-digit Industries } \\ & & -3.40 & -5.63 & -4.12 \\ \text { Total Lost Workdays } & -5.29 & -5.53 & -6.01 & -4.75\end{array}$

1960-70

Based on Quartiles of 46 2-digit Industries

Incidence of Injury $\quad-2.37 \quad-1.80$

Evening/Night Work

1973-91, Men

1973-91, Women

$\theta=.25$

$\theta=.25$

$\begin{array}{lllll}\text { Work evening/night } & -1.37 & -1.30 & 2.16 & 2.21\end{array}$ 
One might argue that these results are not credible, in that it is difficult to believe that the true income elasticities of demand are so large (in absolute value). A number of studies have attempted to estimate income elasticities of demand for the much more readily measured pecuniary nonwage returns to work (mainly pension and health benefits), including doing so as part of a complete system of demand equations. In these studies (e.g., Woodbury and Hamermesh, 1992), the evidence seems quite clear that the demand for those benefits is highly income-elastic. That the demand for nonpecuniary benefits, particularly workplace safety, may be even more income-elastic should perhaps not be surprising.

\section{Conclusion}

Between the 1970s and 1990s the United States saw an increase in the share of the burden of workplace injuries borne by workers in the lower part of the widening distribution of earnings. Those same years were characterized by increased inequality in the burden of work at relatively undesirable times. Obversely, we have shown that the narrowing of wage inequality in the 1960s was accompanied by greater equality in the burden of job injuries, so that the decline in inequality of earnings in that period understates the decline in inequality of full earnings. Taken together, this evidence suggests that concentrating on changing inequality in measured earnings has led us to understate absolute changes in inequality in the total returns to work.

Regardless of the sources of rising wage inequality, its existence provides a consistent explanation of the results in the markets for both disamenities discussed here. One might construct other explanations for these changes. For example, during the 1980s and 1990s there may have been a nonneutral change in employers' abilities to prevent injuries that disproportionately affected lowerwage workers. Simultaneously, employers of low-wage workers may have increasingly found it 
relatively profitable to operate in the evenings or at nights. For this demand- (employer-) -side explanation to be valid requires specific, difficult to envision changes that occurred at the same time in several markets for amenities. Both phenomena are easily rationalized by the simple supply(worker-) side explanation that I have offered.

That there is a consistent explanation for the empirical regularities documented here does not mean that all changes in inequality in markets for workplace amenities are or always will be supplybased, or that changing inequality in earnings always understates the absolute change in inequality in the total returns to work. One can easily envision major technical changes, e.g., the computerization of manufacturing machinery, or the invention of efficient electric lighting, that affect the distribution of amenities differently at various points of the distribution of full earnings. These technical changes, however, have longer-term impacts that are unlikely to be observed over the short periods of time on which the empirical work here (and in most recent studies of changing inequality) has concentrated.

Under the assumptions that changes in the distribution of full earnings are driven by forces exogenous to markets for workplace amenities, that technical change in those markets is skill-neutral, and that underlying preferences for the disamenities are independent of full earnings, the estimates here can be used to derive measures of the income elasticities of demand for the disamenities. This attempt at deriving structural estimates of a parameter underlying the demand for workplace amenities suggests that it is highly income-elastic. More important, these estimates might be usable with other data and under more restrictive assumptions to infer estimates of substitution effects in the demand for those amenities. 
I have examined only two of the many disamenities that workers face on their jobs. Barring large nonneutral technological changes in other markets, we should expect to observe the same relative changes in the burdens of other workplace disamenities in the United States that we have observed here for these two. This suggests that good tests of this approach would apply it to other outcomes in the labor market in the United States since 1970. Moreover, the U.S. provides only one realization of the process of sorting across workers' preferences and employers' costs and only one realization of changing inequality. Our examination of Dutch sectoral data provides some evidence that the same phenomenon might exist in a country where wage inequality is not rising; but more solid tests could be offered if less aggregated, or even micro data were available from countries where changes in the inequality of earnings have not been so extreme as in the United States. Extending this line of research would enable us to expand further beyond our fascination with changing earnings inequality to study changing inequality in labor-market outcomes more generally and to using those changes to understand some basic aspects of labor-market behavior. 


\section{REFERENCES}

Linda Bell and Richard Freeman, "The Causes of Rising Interindustry Wage Dispersion in the United States," Industrial and Labor Relations Review, 44 (1991): 275-87.

Jeff Biddle and Gary Zarkin, "Worker Preferences and Market Compensation for Job Risk," Review of Economics and Statistics, 70 (1988): 660-67.

John Bound and George Johnson, "Changes in the Structure of Wages in the 1980s: An Evaluation of Alternative Explanations," American Economic Review, 82 (1992): 371-92.

Charles Brown, "Equalizing Differences in the Labor Market," Quarterly Journal of Economics, 94 (1980): 113-34.

Greg Duncan and Bertil Holmlund, "Was Adam Smith Right After All? Another Test of the Theory of Compensating Wage Differentials," Journal of Labor Economics, 1 (1983): 366-79.

Henry Farber, "Job Creation in the United States: Good Jobs or Bad?" Industrial Relations Section, Princeton University, Working Paper No. 385, July 1997.

Claudia Goldin and Robert Margo, "The Great Compression: The Wage Structure in the United States at Mid-Century," Quarterly Journal of Economics, 107 (1992): 1-35.

Daniel Hamermesh, Workdays, Workhours and Work Schedules: Evidence for the United States and Germany. Kalamazoo, MI: The W.E. Upjohn Institute, 1996a

"The Timing of Work Time Over Time," National Bureau of Economic Research, Working Paper No. 5855, 1996 b.

and John Wolfe, "Compensating Wage Differentials and the Duration of Wage Loss," Journal of Labor Economics, 8 (1990): S175-97.

J. Daniel Hammond. Theory and Measurement: Causality Issues in Milton Friedman's Monetary Economics. Cambridge: Cambridge University Press, 1996.

Joni Hersch, "Compensating Differentials for Gender-Specific Job Injury Risks," American Economic Review, 88 (1998): forthcoming.

Hae-shin Hwang, W. Robert Reed and Carlton Hubbard, "Compensating Wage Differentials and Unobserved Productivity," Journal of Political Economy, 100 (1992): 835-58.

Eva Jacobs, ed. Handbook of U.S. Labor Statistics. Lanham, MD: Bernan Press, 1997. 
Chinhui Juhn, Kevin M. Murphy and Brooks Pierce, "Wage Inequality and the Rise in Returns to Skill," Journal of Political Economy, 101 (1993): 410-42.

Shulamit Kahn, "Occupational Safety and Worker Preferences: Is There a Marginal Worker?" Review of Economics and Statistics, 69 (1987): 262-68.

Peter Kostiuk, "Compensating Differentials for Shift Work," Journal of Political Economy, 98 (1990): 1054-75.

Organization for Economic Cooperation and Development, Employment Outlook, July 1996. Paris: OECD, 1996.

Sherwin Rosen, "Hedonic Prices and Implicit Markets," Joumal of Political Economy, 82 (1974): 34-55.

John Ruser, "Workers' Compensation and Occupational Injuries and Illnesses," Journal of Labor Economics, 9 (1991): 325-50.

Jack Schmulowitz, "Workers' Compensation: Coverage, Benefits, and Costs, 1992-93," Social Security Bulletin, 58 (Summer 1995): 51-57.

Edward Schumacher and Barry Hirsch, "Compensating Differentials and Unmeasured Ability in the Labor Market for Nurses: Why Do Hospitals Pay More?" Industrial and Labor Relations Review, vol. 50, (July), pp. 557-79.

Matthew Shapiro, "Capital Utilization and the Marginal Premium for Work at Night," Unpublished paper, University of Michigan, 1995.

Hal Sider, "Work-Related Accidents and the Production Process," Journal of Human Resources, 21 (1985): 271-80.

Frank Stafford, "Firm Size, Workplace Public Goods, and Worker Welfare," in John Siegfried, ed., The Economics of Firm Size, Market Structure and Social Performance. Washington: Federal Trade Commission, 1980.

and Greg Duncan, "Do Union Members Receive Compensating Wage Differentials?" American Economic Review, 70 (1980): 355-71.

Daniel Suits, "Measurement of Tax Progressivity," American Economic Review, 67 (1977): 747-52.

U. S. Department of Labor, Handbook of Labor Statistics. Washington: GPO, various years. 
Amy Wolaver, Timothy McBride and Barbara Wolfe, "Decreasing Opportunities for Low-Wage Workers: The Role of the Nondiscrimination Law for Fringe Benefits," Unpublished Paper, University of Wisconsin-Madison, December 1996.

Stephen Woodbury and Daniel , "Taxes, Fringe Benefits and Faculty," Review of Economics and Statistics, 74 (1992): 287-96. 


\section{FOOTNOTES}

1. Two of the many examples from the substantial literature dealing specifically with the compensating wage differential for risk of injury are Biddle and Zarkin (1988) and Sider (1985).

2. In Hamermesh (1996b) I examine trends in the burden of evening and night work (and, more generally, in diurnal patterns of work timing).

3. A number of attempts were made to circumvent this problem. Cross-section studies obviously cannot solve this identification problem; but even longitudinal studies, of which Duncan and Holmlund (1983) is one of the most clever, suffer from an inability to distinguish changes in eamings due to changes in the wage-risk trade-off from those due to changes in full earnings.

4. I thank John Goddeeris for pointing out this potential problem.

5. Beginning in 1992 BLS ceased publishing industry averages of DUR and began presenting the data as a frequency distribution, with the topcoded value of 30 . Evidence from micro data for 1993, kindly provided to me by Geetha Waehrer, suggested that the right tails of the distributions of injury duration within industries are very thick, with the average duration of injuries in the topcoded interval typically being 80 to 100 days. To make these data as comparable to those from $1979-91$ as possible, I took the average in the topcoded interval for 1993 and calculated the weighted average duration for each year 1992-95.

6. None of the conclusions presented in the next section changes qualitatively if the analysis is extended to include all the industries (is based on an unbalanced panel).

7. This is obviously only one of a variety of ways to make these comparisons. One could, as has been done to measure the progressivity of taxation, construct one-parameter analogues to Gini coefficients (Suits, 1977).

8. One might be concerned that changes in the distribution of injuries might have been affected by changes in workers' compensation benefits, since it is clear (e.g., Ruser, 1991) that higher benefits raise reported rates of workplace accidents. Workers' compensation costs, both medical and paid compensation, increased through 1992 in our sample period, although there is some evidence (Schmulowitz, 1995), that this was reversed in 1993. Regrettably one cannot tell from any available data whether the increase in compensation costs resulted from growth in rates of injury among those injuries eligible for coverage, or from greater generosity of benefits for each particular injury that might have induced increases in reported workplace injuries. If this latter effect occurred, however, it seems likely to have been reflected mostly in DUR, not in INC. This underscores the attention paid here to changing inequality in the incidence of injuries.

9. One could almost as easily take the obverse approach and sort the industries by the particular component of injuries, e.g., INC, and then compare how relative earnings change over time by quartile of the distribution of INC. Taking this approach unsurprisingly yields the same qualitative conclusions: Relative earnings fall between 1979 and 1995 in those industries that are in the upper quartile of the distribution of injury risk (INC) or total lost workdays (TOTINJ) compared to those in the bottom quartile.

10. Although this test does control in part for the role of differences in technology, the slow changes that occur in relative earnings across industries mean that we should not expect the results to change greatly. Eight (7) of the 13 industries in the top (bottom) decile of the industrial distribution of earnings in 1979 
were in the same decile in 1995. (Also, 27 (23) of the 33 industries in the top (bottom) quartile in 1979 were in the same quartile in 1995.) The eight industries are metal mining, coal mining, petroleum and natural gas extraction, drug manufacturing, petroleum refining, miscellaneous communication services, security and brokerage workers, and engineering, architectural and surveying services. The seven industries are apparel manufacturing, variety stores, gas service stations, shoe stores, eating and drinking places, building services, and laundry services.

11. The trend in the inter- (earnings) quartile difference in INC is $-0.036($ s.e. $=0.013$ ) over the seventeen years.

12. That the total burden jumped in 1992 is due solely to the one-time jump in the $90-10$ difference in the duration of injuries, a change almost certainly due to the revised method used to calculate injury duration.

13. Workers with hourly earnings (weekly earnings divided by usual hours) below $\$ 1$ in 1973 and $\$ 2.75$ in 1991 were excluded from the analysis.

14. Other approaches, such as examining differences in the fractions of workers in each earnings decile who are at work at each hour of the day, yield the same qualitative conclusions.

15. The entire discussion has proceeded absent any consideration of the role of the flattening of the structure of marginal (income) tax rates that occurred in the United States during the 1980s. This tax change presumably led higher-wage workers to "spend" relatively less of their full earnings on reducing disamenities and to take more in the form of earnings. Had tax rates not changed, we would thus have observed a smaller widening of inequality of measured earnings; but if we could have accounted for tax changes, the adjustments made here would have generated still larger changes in the inequality of full earnings.

16. This definition results in 12.0 percent of the full-time male workers being classified as evening/night workers and 8.3 percent of the full-time females being thus classified. 